\title{
Nutritional Regime of the Soil and Growth Activity of the Apple Tree Root System in Orchards with Legume-Cereal Grass Intercropping
}

\author{
Aleksandr Gurin ${ }^{1}$, Svetlana Rezvyakova ${ }^{1, *}$, and Nikolay Revin ${ }^{1}$ \\ ${ }^{1}$ Oryol State Agricultural University named after N.V. Parakhin, Generala Rodina Str., 69, Oryol, 302019, Russia
}

\begin{abstract}
This work aims to study the influence of legume-cereal grasses in the inter-row spacings of the garden on the content of nutrients in the soil and the growth of apple tree roots. The amount of nitrate nitrogen was in direct proportion to the ratio of the legume component in the phytocenosis. The nitrogen content in the control option was the smallest: $19.7 \mathrm{mg} / \mathrm{kg}$ in the soil layer of $0-30 \mathrm{~cm}$ and $13.4 \mathrm{mg} / \mathrm{kg}$ in the layer of 30-60 cm. In the case of natural grassing-down between rows, cereal forbs prevailed. The largest amount of nitrate nitrogen was achieved when sowing the red clover and timothy grass in a ratio of 7:3. The accumulation of nitrate nitrogen is due to the activity of nodule bacteria on the roots of red clover. The accumulation of mobile phosphorus and exchangeable potassium depends on the amount of mowed mass in the inter-row spacings of the garden. The lowest content of mobile phosphorus was detected for natural grassing. In the control option, its amount was $118 \mathrm{mg} / \mathrm{kg}$. In the $0-30 \mathrm{~cm}$ soil layer, the content of mobile phosphorus was $127.4-142.6 \mathrm{mg} / \mathrm{kg}$ depending on the ratio of legume-cereal grasses, and it amounted to $95.1-103.2 \mathrm{mg} / \mathrm{kg}$ in the $30-60 \mathrm{~cm}$ layer. For the ratio of red clover and timothy grass $3: 7$, the highest phosphorus content was detected. The intercropping of the garden with a legume-cereal herbal mixture also contributed to a greater accumulation of exchangeable potassium in the soil relative to natural grassingdown - 122.3-134.9 mg/kg. The optimal ratio of legume-cereal component was 3:7. A higher growth activity of the roots of the apple tree was noted in the option with sodding with a mixture of red clover and timothy grass in a ratio of 7:3.
\end{abstract}

\section{Introduction}

The root system of a fruit tree is an important organ. It absorbs water and dissolved minerals from the soil and forms organic compounds. It is possible to obtain high and stable yields only under the conditions that ensure the active vital activity of the root system during the entire growing season [1]. Soil maintenance systems have a significant impact on the growth processes of the root system [2]. Continuous grassing-down of the interrow spacings inhibits the growth of fruit crops roots, which affects the condition of the entire fruit tree [3, 4]. The suppression of growth activity is explained, first of all, by the competition between fruit crops and grasses for moisture and nutrients $[5,6,7]$.

The sod-humic system of soil maintenance in interrow spacings of the garden eliminates the indicated disadvantage of continuous grassing-down. This is achieved by repeatedly mowing of grass and leaving it on the ground. The decomposing aboveground mass and dying root system of perennial grasses enrich the soil with mineral nutrition elements [8-10]. It must be borne in mind that fruit trees first of all need nitrogen for their growth. Therefore, to enrich the soil with this element, it is necessary to introduce perennial leguminous plants into the composition of grass mixtures, which are capable of fixing atmospheric nitrogen [11-13]. In industrial gardens, grassing-down of inter-row spacings are mainly produced by natural fire-fanging [14] or sowing of perennial grasses $[15,16]$. The impact of legume-cereal grasses was insufficiently studied in Russia, and their influence in the conditions of the forest-steppe zone wasn't studied at all.

This work aims to study the influence of legumecereal grass in inter-row spacings of the garden on the content of nutrients in the soil and the growth activity of the apple tree root system.

\section{Materials and methods}

The experiments were conducted in 4 options:

1. Natural grassing-down (control);

2. Red clover (Trifolium pratence) $50 \%+$ Timothy grass (Phleum pratence) $50 \%$;

3. Red clover (Trifolium pratence) $70 \%+$ Timothy grass (Phleum pratence) 30\%;

4. Red clover (Trifolium pratence) $30 \%+$ Timothy grass (Phleum pratence) $70 \%$.

The experiments were carried out in an apple orchard planted in 1989 (ZAO Sosnovka, Livensky district,

\footnotetext{
*Corresponding author: lana8545@yandex.ru
} 
Oryol region, Russia). The trees layout was $7 \times 5 \mathrm{~m}$, the seedling rootstock Sinap Orlovsky was used. Inter-row garden spacings were grassed-down. Sowing of perennial grasses was carried out in the spring of 2015 . The experiment was repeated three times, the area of the accounting plot was $280 \mathrm{~m}^{2}$. There were 24 count trees in a repetition. Placement of options was randomized.

The soil of the experimental site was ordinary chernozem, loam silt-clay according to the granulometric composition (Chernozem Aric), the humus content was $5.34 \%, \mathrm{pH}$ was 5.87 . The mowing and grinding of the aboveground mass was carried out as the plants grew to a height of 15-20 cm. Soil samples were taken at the crown periphery, during the period of maximum root growth. The growth activity of the apple tree root system was studied by the method of V.A. Kolesnikov [17]. For this, $1 / 2$ of the root system $(4.0 \times 1.25 \mathrm{~m})$ was dug to a depth of $1.0 \mathrm{~m}$ in sectors every $0.5 \mathrm{~m}$. The depth was 0.2 $\mathrm{m}$. Rectangular monoliths $0.5 \times 1.25 \times 0.2 \mathrm{~m}$ in size were selected. 40 samples were taken for each tree. The roots were classified according to diameters: 1-3 $\mathrm{mm}$ for absorbing, 3-5 $\mathrm{mm}$ for intermediate, 5-10 $\mathrm{mm}$ for conducting. The roots were arranged according to their diameters, after that their length was measured.

The content of nitrate nitrogen was determined by the colorimetric method according to Granval-Lyazh [18]. The nitrate content was determined potentiometrically by measuring the activity of nitrate ions with an ionselective electrode in a salt suspension of a $1 \%$ solution of potassium alum. Soil samples weighing $20.0 \mathrm{~g}$ were weighed with an error of no more than $0.1 \mathrm{~g}$ and placed in technological containers or conical flasks. The samples were poured into $50 \mathrm{~cm}^{3}$ of the extraction solution. The sample with the solution was mixed in a shaker for 3 minutes.

The suspension was shaken before measurements. The electrode pair was immersed in the suspension and the device readings were recorded not earlier than $1 \mathrm{~min}$ after the termination of the noticeable drift of the instrument readings. Mobile phosphorus was assessed by photometry using the KFK-3 photometer at a wavelength of $710 \mathrm{~nm}$. To determine the content of mobile compounds of phosphorus and exchangeable potassium, soil samples weighing $(4.0 \pm 0.1) \mathrm{g}$ were placed in conical flasks. $100 \mathrm{ml}$ of the extraction solution was poured to the samples. The soil with the solution was mixed for 1 hour and left in an upright position for 1820 hours. Then the suspension was shaken by hand and filtered through paper filters. In the resulting filtrate, after staining with reagent $\mathrm{B}$, the content of mobile phosphorus was determined. Photometry was carried out in a cell with a $2 \mathrm{~cm}$ translucent layer relative to reference solution No. 1. Potassium was determined using the Jenway PFP-7 flame photometer using a light filter with a maximum transmission in the range of 766$770 \mathrm{~nm}$ according to Chirikov modified by TsINAO [19].

\section{Results and discussion}

The botanical composition of the herbage in the interrow spacings of the apple orchard influenced the content of nutrients in the soil (Table 1).

Table 1. The content of nutrients in the soil as a function of the botanical composition of legume-cereal grasses in inter-row spacings of an apple orchard (2017-2019).

\begin{tabular}{|l|c|c|c|c|c|c|}
\hline $\begin{array}{c}\text { Experimental } \\
\text { options }\end{array}$ & $\begin{array}{c}\text { Nitrate } \\
\text { nitrogen, } \\
\mathbf{m g} / \mathbf{k g}\end{array}$ & $\begin{array}{c}\text { Mobile } \\
\text { phosphorous, } \\
\mathbf{m g} / \mathbf{k g}\end{array}$ & $\begin{array}{c}\text { Exchangeable } \\
\text { potassium, } \\
\mathbf{m g} / \mathbf{k g}\end{array}$ \\
\cline { 2 - 7 } & $\begin{array}{c}0-30 \\
\mathrm{~cm}\end{array}$ & $\begin{array}{c}30-60 \\
\mathrm{~cm}\end{array}$ & $\begin{array}{c}0-30 \\
\mathrm{~cm}\end{array}$ & $\begin{array}{c}30-60 \\
\mathrm{~cm}\end{array}$ & $0-30 \mathrm{~cm}$ & $\begin{array}{c}30-60 \\
\mathrm{~cm}\end{array}$ \\
\hline $\begin{array}{l}\text { Natural } \\
\text { grassing-down } \\
\text { (control) }\end{array}$ & 19.7 & 13.4 & 118.3 & 89.7 & 124.9 & 117.6 \\
\hline $\begin{array}{l}\text { Red clover 50\% } \\
+ \text { Timothy grass } \\
\text { 50\% }\end{array}$ & 27.9 & 18.2 & 131.4 & 97.9 & 143.6 & 128.4 \\
\hline $\begin{array}{l}\text { Red clover 70\% } \\
+ \text { Timothy grass } \\
30 \%\end{array}$ & 36.9 & 21.1 & 127.4 & 95.1 & 134.8 & 122.3 \\
\hline $\begin{array}{l}\text { Red clover 30\% } \\
+ \text { Timothy grass } \\
70 \%\end{array}$ & 23.6 & 15.7 & 142.6 & 103.2 & 156.1 & 134.9 \\
\hline HCP 05 & 2.41 & 1.26 & 11.06 & 7.33 & 12.14 & 8.32 \\
\hline
\end{tabular}

Soil cultivation is known to increase nitrate nitrogen. Intercropping by legume-cereal perennial grasses is a widespread cultivation technique. The main supplier of nitrogen is legumes, including red clover, which can fix nitrogen in air and soil up to $150 \mathrm{~kg}$ per hectare. The amount of nitrate nitrogen was in direct proportion to the ratio of the legume component in the phytocenosis. Under natural grassing-down of inter-row spacings, cereal grasses prevailed. The nitrogen content in the control option was the smallest: $19.7 \mathrm{mg} / \mathrm{kg}$ in the $0-30$ $\mathrm{cm}$ soil layer and $13.4 \mathrm{mg} / \mathrm{kg}$ in the $30-60 \mathrm{~cm}$ layer. For the second option, with the ratio of red clover and timothy grass $1: 1$, the content of nitrate nitrogen in the soil layers was $27.9 \mathrm{mg} / \mathrm{kg}$ and $18.2 \mathrm{mg} / \mathrm{kg}$, respectively. The largest amount of nitrate nitrogen was registered for the option with sowing of red clover $(70 \%)$ and timothy grass $(30 \%)$. In the $0-30 \mathrm{~cm}$ soil layer, the amount of nitrogen was $36.9 \mathrm{mg} / \mathrm{kg}$ and in the $30-60 \mathrm{~cm}$ layer it was $21.1 \mathrm{mg} / \mathrm{kg}$. The minimum amount of nitrate nitrogen was for the option with sowing leguminouscereal grasses in a ratio of $3: 7-23.6 \mathrm{mg} / \mathrm{kg}$ in a soil layer of $0-30 \mathrm{~cm}$ and $15.7 \mathrm{mg} / \mathrm{kg}$ in a layer of $30-60 \mathrm{~cm}$.

The accumulation of nitrate nitrogen is governed by the activity of nodule bacteria on the roots of red clover. In contrast to it, the accumulation of mobile phosphorus and exchangeable potassium depended on the amount of mowed mass in the inter-row spacings of the garden.

The lowest content of mobile phosphorus was registered for the option with natural grassing-down. In the $0-30 \mathrm{~cm}$ soil layer, its amount was $118 \mathrm{mg} / \mathrm{kg}$, in the $30-60 \mathrm{~cm}$ layer it was $89.7 \mathrm{mg} / \mathrm{kg}$. The presence of legume-cereal vegetation in the inter-row spacings of the garden ensured a greater accumulation of this element in the soil. In the $0-30 \mathrm{~cm}$ soil layer, the content of mobile phosphorus was $127.4-142.6 \mathrm{mg} / \mathrm{kg}$ depending on the 
ratio of legume-cereal grasses, in the $30-60 \mathrm{~cm}$ layer it was $95.1-103.2 \mathrm{mg} / \mathrm{kg}$. For the option with the ratio of red clover and timothy grass 3:7, the highest phosphorus content was noted. As it was mentioned above, the amount of accumulated nutrients in the soil is determined, first of all, by the mass of the mown vegetation. Of no less importance is the fact that the mineralization of the biomass of leguminous and cereal grasses is carried out rather quickly. In this case, there is an increase in enzymatic activity in the soil and the accumulation of nutrients. In this option, the largest amount of aboveground plant mass was formed.

Fire-fanging of the garden inter-row spacings by the legume-cereal herb mixture also contributed to a greater accumulation of exchangeable potassium in the soil as compared with natural grassing-down. The content of exchangeable potassium for these options was 134.8$156.1 \mathrm{mg} / \mathrm{kg}$ in the $0-30 \mathrm{~cm}$ layer and $122.3-134.9 \mathrm{mg} / \mathrm{kg}$ in the $30-60 \mathrm{~cm}$ layer. The maximum amount of this element was noted for the option with the legume-cereal component ratio of 3:7. The potassium content in the soil for this option, on average, over three years was 156.1 $\mathrm{mg} / \mathrm{kg}$ in the $0-30 \mathrm{~cm}$ layer and $134.9 \mathrm{mg} / \mathrm{kg}$ in the $30-60$ $\mathrm{cm}$ layer.

We studied the growth of overgrowing roots of an apple tree of seed origin. Overgrowing roots, both in number and in total length, are the main part of the root system of woody plants. They absorb water and minerals and, together with the leaves, produce organic compounds that provide growth processes and the formation of yields of fruit plants. The most important are the following types of overgrown roots:

- absorbing, or active, roots of the primary structure, their main function is the absorption of water and minerals from the soil. They are distinguished by high physiological activity, especially during periods of massive root growth;

- intermediate roots of the primary structure, serve as a good indicator of the growth of the root system;

- conducting roots of a secondary structure, light or dark brown in color, their main function is to supply water and nutrients to the plant.

The increased content of nutrients in the soil under grassing-down with legume-cereal grasses had a positive effect on the activation of growth processes in the root system of apple trees in the experiment (Table 2).
Table 2. Growth activity of apple root system under the influence of grassing-down of inter-row spacings with legumecereal grasses (2017-2019).

\begin{tabular}{|c|c|c|c|c|c|c|c|}
\hline \multirow{3}{*}{ Options } & \multirow{3}{*}{$\begin{array}{l}\text { Soil } \\
\text { layer, } \\
\text { cm }\end{array}$} & \multicolumn{6}{|c|}{ The amount of roots } \\
\hline & & \multicolumn{2}{|c|}{ Absorbing } & \multicolumn{2}{|c|}{ Intermediate } & \multicolumn{2}{|c|}{ Conducting } \\
\hline & & pes. & $\mathrm{m}$ & pes. & $\mathrm{mm}$ & pes. & $\mathrm{mm}$ \\
\hline \multirow{2}{*}{$\begin{array}{l}\text { Natural } \\
\text { grassing- } \\
\text { down } \\
\text { (control) }\end{array}$} & $0-30$ & 67 & 113 & 72 & 137 & 32 & 324 \\
\hline & $30-60$ & 41 & 70 & 37 & 73 & 26 & 312 \\
\hline \multirow{2}{*}{$\begin{array}{l}\text { Red } \\
\text { clover } \\
50 \%+ \\
\text { Timothy } \\
\text { grass } 50 \%\end{array}$} & $0-30$ & 83 & 141 & 89 & 179 & 39 & 468 \\
\hline & $30-60$ & 48 & 82 & 43 & 86 & 28 & 336 \\
\hline \multirow{2}{*}{$\begin{array}{l}\text { Red } \\
\text { clover } \\
70 \%+ \\
\text { Timothy } \\
\text { grass } 30 \%\end{array}$} & $0-30$ & 107 & 181 & 116 & 231 & 43 & 518 \\
\hline & $30-60$ & 56 & 95 & 64 & 127 & 30 & 358 \\
\hline \multirow{2}{*}{$\begin{array}{l}\text { Red } \\
\text { clover } \\
30 \%+ \\
\text { Timothy } \\
\text { grass } 70 \%\end{array}$} & $0-30$ & 74 & 125 & 78 & 156 & 34 & 409 \\
\hline & $30-60$ & 44 & 75 & 39 & 77 & 28 & 334 \\
\hline \multirow{2}{*}{$\mathrm{HCP}_{05}$} & $0-30$ & 3.21 & 10.13 & 6.39 & 11.21 & 1.32 & 27.54 \\
\hline & $30-60$ & 2.17 & 6.71 & 3.04 & 6.83 & 1.14 & 21.16 \\
\hline
\end{tabular}

For the control option (natural grassing-down), the number of suction roots in the $0-30 \mathrm{~cm}$ soil layer was 67 , and their length was $113 \mathrm{~mm}$. In the layer of 30-60 cm, there were fewer suction roots (41), and their length was $70 \mathrm{~mm}$. For the options with grassing-down by legumecereal grasses, there were more absorbing roots, 74 to 107 depending on the botanical ratio of components in the soil layer $0-30 \mathrm{~cm}$ and $44-56$ in a layer of $30-60 \mathrm{~cm}$. The length of the absorbing roots was $125-181 \mathrm{~mm}$ and $75-95 \mathrm{~mm}$, respectively. The largest amount of absorbing roots was for the option with red clover (70\%) and timothy grass $(30 \%)$.

A similar pattern was noted for the number of intermediate roots. The smallest amount of them and, accordingly, the smallest length were registered for the control variant - $72 \mathrm{pcs}$. and $137 \mathrm{~mm}$ in the soil layer 0$30 \mathrm{~cm}$ and $37 \mathrm{pcs}$. and $73 \mathrm{~mm}$ in the $30-60 \mathrm{~cm}$ layer. For options with sowing of cultivated grasses, the number of intermediate roots increased by $8.3-61.1 \%$ in the $0-30$ $\mathrm{cm}$ layer and by $5.4-70.1 \%$ in the $30-60 \mathrm{~cm}$ layer. The maximum amounts of intermediate and absorbing roots were registered in the third option.

The maximum amount of conducting roots was detected for the options legume-cereal grasses: 4-43 pcs. in the soil layer $0-30 \mathrm{~cm}$, against 32 pcs. in the control variant. The length of the roots was also 9.3-38.5\% longer than in the control variant. The largest number of conducting roots was found for the option with red clover (70\%) and timothy grass (30\%).

\section{Conclusion}

Thus, the highest growth activity of apple tree roots was observed for the option with grassing-down by a mixture 
of red clover and timothy grass in a ratio of 7:3. Consequently, the growth activity of the apple tree root system primarily depends on the supply of nitrogen to the soil. Therefore, the introduction into the botanical composition of the legume component in the form of red clover when grassing-down inter-row spacings of an apple orchard will maintain a high activity of the root system of trees throughout the growing season without the use of mineral fertilizers.

\section{References}

1. C. Sławiński, J. Cymerman, B. WitkowskaWalczak, K. Lamorski, Impact of diverse tillage on soil moisture dynamics, Int., Agrophys., 26, 301-309 (2015)

2. A.S. Devyatov, The root system of fruit trees: Apple, pear, cherry, plum (Publishing house of the Institute of Fruit Growing of the National Academy of Sciences of Belarus, 2003, 254)

3. V.A. Kolesnikov, Methodology of laboratory and field experiment for the study of the root system of fruit and berry plants (Moscow, Kolos, 1960, 1013)

4. A.I. Kozhukhov, A.G. Gurin, S.V. Rezvyakova, Main elements of nutrition content in the soil for maize crops, depending on the predecessors and methods of soil treatment, E3S Web Of Conferences, International Conference on Efficient Production and Processing, ICEPP 2020 DOI: $10.1051 / \mathrm{e} 3$ sconf $/ 202016101103$

5. N.Yu. Revin, A.G. Gurin, S.V. Rezvyakova, Nitrogen regime of the soil with a sod-humus system of inter-row spacings in an apple orchard, Vestnik Agrarnoy Nauki, 2 (83), 29-35 (2020) DOI: 10.172381/issn2587-666x.2020.2.29

6. M.V. Pridorogin, The value of the sod-humus system of soil maintenance in an intensive apple orchard, Agrarian journal, 10, 39-42 (2010)

7. V.P. Popova, Agroecological aspects of the formation of productive garden ecosystems (Krasnodar, 2005, 242)

8. A.V. Buzoverov, T.N. Doroshenko, L.G. Ryazanova, Optimization of soil fertility of apple trees in non-irrigated orchards, Nauchnye trudy of GNU SKZNIISiV, 3, 65-70 (2013)

9. F. Akbas, H. Gunal, N. Acir, Spatial variability of soil potassium and its relation to land use and parent material, Soil\&Water Res., 12, 202-211 (2017) DOI: 10.17221/32/2016-SWR
10. M. Kulhánek, J. Černý, J. Balík, O. Sedlář, F. Vašák, Changes of soil bioavailable phosphorus content in the long-term field fertilizing experiment, Soil \& Water Res, 14, 240-245 (2019) DOI: 10.17221/175/2018-SWR

11. N. Gougoulias, G. Papapolymerou, V. Karayannis, X. Spiliotis, N. Chouliaras, Effects of manure enriched with algae Chlorella vulgaris on soil chemical properties, Soil\&Water Res., 13, 51-59 (2018) DOI: 10.17221/260/2016-SWR

12. A.K. Indoria, R.Ch. Srinivasa, K.L. Sharma, R.K. Sammi, Conservation agriculture - a panacea to improve soil physical health, Current science, 112 (1) (2017)

13. J. Janků, P. Sekáč, J. Barákova, J. Kozák, Land use analysis in terms of farmland protection in the Czech Republic, Soil\&Water Res., 11, 20-28 (2016) DOI: 10.17221/163/2015-SWR

14. V.L. Zakharov, N.V. Morgacheva, Use of pome fruit stock of apple trees for soils bioindication in the North of Central black earth economic region, IOP Conference Series: Earth and Environmental Science, 315 (2), 022009 (2019) DOI: 10.1088/1755-1315/315/2/022009

15. N.Yu. Revin, A.G. Gurin, S.V. Rezvyakova, The role of legume-cereals grass mixtures for detritus formation in the soiland its water penetration in the sod-humus system of apple orchard row spacings, Plodovodstvo i vinogradarstvo Yuga Rossii, $64 \quad$ (4), 282-292 (2020) DOI: $10.30679 / 2219-5335-2020-4-64-282-292$

16. F.N. Rykalin, The effect of root growth activity on apple tree yield under different systems of soil maintenance in an irrigated garden, Izvestia of the Orenburg State Agrarian University, 2 (30), 12-15 (2011)

17. M.V. Pridorogin, Environmental stress created in apple orchards by the steam system of soil maintenance and the ability to avoid it, Bulletin of Michurinsky State Agrarian University, 3, 111119 (2012)

18. GOST 26204-91, Soils, Determination of mobile compounds of phosphorus and potassium by the Chirikov method modified by TsINAO (Moscow, Publishing house of standards, 1992, 6)

19. E.V. Arinushkina, Manual for Chemical Analysis of Soils (Moscow, Publishing House of the Moscow State University, 1970, 427) 